Article

\title{
Optimization of A354 Al-Si-Cu-Mg Alloy Heat Treatment: Effect on Microstructure, Hardness, and Tensile Properties of Peak Aged and Overaged Alloy
}

\author{
Stefania Toschi (D) \\ Department of Industrial Engineering (DIN), Alma Mater Studiorum-University of Bologna, \\ Viale Risorgimento 4, 40136 Bologna, Italy; stefania.toschi3@unibo.it; Tel.: +39-051-209-3462
}

Received: 31 October 2018; Accepted: 14 November 2018; Published: 17 November 2018

\begin{abstract}
The aim of the present work is the study of T6 heat treatment of A354 (Al-Si-Cu-Mg) casting alloy. The heat treatment was optimized by maximizing mechanical strength of the alloy while keeping the treatment cost effective, reducing treatment time and temperature. Due to the presence of low melting compounds, a double stage solution treatment was proposed. The first stage was aimed at the homogenization and dissolution of the low melting phase while a second stage at a higher temperature was evaluated to foster dissolution of $\mathrm{Cu} / \mathrm{Mg}$ rich intermetallics and keep the solution time and temperature as low as possible. Microstructural investigations were performed through optical and electronic microscopy, which allowed the assessment of the evolution of intermetallic phases during the solution treatment. Artificial aging was studied at different temperatures from $160{ }^{\circ} \mathrm{C}$ to $210^{\circ} \mathrm{C}$ where the peak aging condition was identified. Over aging of the heat treated alloy was evaluated by soaking T6 samples at 200, 245, and $290^{\circ} \mathrm{C}$ for up to $168 \mathrm{~h}$. Tensile behavior of the T6 and over-aged alloy (i.e., after soaking at $210^{\circ} \mathrm{C}$ for $50 \mathrm{~h}$ ) was evaluated at room temperature. Results showed that the proposed treatment allowed the enhancement of mechanical properties of the alloy in comparison to industrial practice treatment, maintaining a good level of ductility and conferring a superior resistance to long-term high temperature exposure.
\end{abstract}

Keywords: A354; Al-Si-Cu-Mg alloys; microstructure; heat treatment; over aging

\section{Introduction}

Al-Si cast aluminium alloys are commonly used in the transport sector for the production of a large variety of components. Al-Si-Mg alloys, characterized by excellent castability, enable the production of complex-shape parts with high specific strength due to their response to aging treatment. The application field of such alloys is, however, strongly influenced by the component operating temperature: mechanical properties of heat treatable cast Al-Si-Mg alloys (e.g., A356) are, in fact, negatively affected by high temperature exposure $\left(\mathrm{T} \geq 200{ }^{\circ} \mathrm{C}\right)$ [1]. As a result of the coarsening of strengthening precipitates generated during artificial aging, a noticeable reduction of hardness and tensile strength occurs at temperatures close to or higher than $200{ }^{\circ} \mathrm{C}$. The more demanding requirements concerning fuel emission reduction or performance enhancement are leading towards engine downsizing design concepts, which induce higher thermo-mechanical loads on engine components.

Aiming to ensure a superior thermal stability to cast aluminium alloys for applications such as diesel engines, copper is added to the traditional Al-Si-Mg alloys [2-9]. The concomitant presence of both copper and magnesium in Al-Si-Cu-Mg alloys enables the precipitation of more stable Cu-based intermetallic phases, which confers to the T6 alloys an increased thermal stability in comparison to 
traditional Al-Si-Mg alloys. Further than $\beta\left(\mathrm{Mg}_{2} \mathrm{Si}\right)$ and $\theta\left(\mathrm{Al}_{2} \mathrm{Cu}\right)$ precipitates, present in ternary $\mathrm{Al}-\mathrm{Si}-\mathrm{Mg}$ and $\mathrm{Al}-\mathrm{Si}-\mathrm{Cu}$ alloys, the quaternary $\mathrm{Q}$ phase (whose general stoichiometry is $\mathrm{Al}_{5} \mathrm{Cu}_{2} \mathrm{Mg}_{8} \mathrm{Si}_{6}$ ) is found in Al-Si-Cu-Mg alloys [7,10]. As recently investigated by Farkoosh et al. [7], this phase is expected to give the most relevant contribution to thermal stability enhancement since it is the only age-hardening phase stable after soaking at $300^{\circ} \mathrm{C}$ for $100 \mathrm{~h}$ [7].

Aiming to exploit the full potential of Al-Si-Cu-Mg alloys, the optimization of the T6 heat treatment is crucial and needs to be addressed for each specific alloy composition by defining proper solution treatment parameters and artificial aging conditions. The present work aims to investigate the optimization of $\mathrm{T} 6$ heat treatment for the A354 (Al-Si-Cu-Mg) alloy, which is employed for the production of cast engine components and aims to maximize hardness and tensile properties while maintaining the treatment cost-effective. The study took into consideration the incipient melting of $\mathrm{Cu}$-based phases, which are known to characterize quaternary $\mathrm{Al}-\mathrm{Si}-\mathrm{Cu}-\mathrm{Mg}$ alloys and require particular care in defining solution treatment parameters [4,11,12]. Microstructural evolution during solution treatment, aging and over aging of the alloy were investigated as well as the mechanical behavior of the alloy heat treated according to the optimized treatment parameters.

\section{Materials and Methods}

\subsection{Castings Production}

Commercial A354 alloy was melted in an induction furnace at $750{ }^{\circ} \mathrm{C}$ under Ar atmosphere. Strontium was added in the form of Al-Sr10 master alloy (300 ppm) with the aim to refine and spherodize the eutectic Si. The melt was electromagnetically stirred and poured in a permanent steel die pre-heated at $300{ }^{\circ} \mathrm{C}$. From the cast ingot, cylindrical bars for experimental activities were obtained. The chemical composition of the cast A354 alloy was evaluated by Glow Discharge Optical Emission Spectroscopy (GDA-650 GDOES: Spectruma Analytik GmbH, Hof, Germany). Results are reported in Table 1. The average value of the Secondary Dendrite Arm Spacing (SDAS) and aspect ratio of eutectic silicon particles were calculated through optical microscopy (Axio Imager Optical Microscope: Zeiss, Oberkochen, Germany) by image analyses.

Table 1. Chemical composition (wt.\%) of A354 alloy measured on the castings by GDOES.

\begin{tabular}{ccccccc}
\hline $\mathbf{S i}$ & $\mathbf{C u}$ & $\mathbf{M g}$ & $\mathbf{F e}$ & $\mathbf{M n}$ & $\mathbf{T i}$ & Al \\
\hline 8.608 & 1.746 & 0.467 & 0.113 & 0.003 & 0.122 & Bal. \\
\hline
\end{tabular}

\subsection{Heat Treatment Optimization}

From the cast bars, small blocks of $10 \times 10 \times 6 \mathrm{~mm}^{3}$ were cut for optimizing solution heat treatment and artificial aging conditions. T6 heat treatment optimization was carried out in the following steps.

(i) Solution treatment optimization-1st stage

Differential thermal analysis (DTA) was performed on the as-cast A354 alloy in order to evaluate the presence of low temperature melting compounds. The analyses were carried out in Ar gas from room temperature to $700{ }^{\circ} \mathrm{C}$, at $10^{\circ} \mathrm{C} / \mathrm{min}$ heating rate using samples of about $20 \mathrm{mg}$. This analysis defined the temperature of the first solution treatment stage $\left(495^{\circ} \mathrm{C}\right)$.

A354 samples were then solution-treated at $495^{\circ} \mathrm{C}$ for different times ( $30 \mathrm{~min}, 4,5$, and $6 \mathrm{~h}$ ). DTA analyses were then carried out on the solution treated samples in order to verify the minimum time required for the homogenization and dissolution of the polinary eutectic phase, defining the time-temperature conditions of the first solution stage. Some samples were quenched in hot water $\left(60^{\circ} \mathrm{C}\right)$ after solution treatment and then aged at a fixed condition $\left(200^{\circ} \mathrm{C}-2 \mathrm{~h}\right)$ in order to evaluate the hardness increase obtained through the first solution stage. 


\section{(ii) Solution Treatment Optimization-2nd Stage}

Samples were solution treated as previously defined. Then the temperature was raised to 515 or $530{ }^{\circ} \mathrm{C}$ and kept constant for 2, 4, 6, and $8 \mathrm{~h}$. After solutioning, samples were quenched in hot water $\left(60^{\circ} \mathrm{C}\right)$ and aged at a fixed condition $\left(200^{\circ} \mathrm{C}-2 \mathrm{~h}\right)$. The aim was to evaluate the condition that maximizes hardness while keeping at a minimum both the solution time and the temperature.

\section{(iii) Artificial Aging Optimization}

Samples were solution treated at the optimized conditions, quenched in hot water $\left(60{ }^{\circ} \mathrm{C}\right)$, and then artificially aged at different temperatures $\left(160,180,190,200\right.$, and $210^{\circ} \mathrm{C}$ ) and times (from 1 to $48 \mathrm{~h}$ ). The optimal aging condition was defined as the time-temperature combination maximizing the hardness of the alloy.

The optimized heat-treated condition for A354 alloy is hereafter referred to as $\mathrm{T} 6^{*}$. In all the above mentioned experimental steps, samples were subjected to Brinell hardness measurement, according to the ASTM E10-08 standard [13], by using a load of $62.5 \mathrm{~kg}$ and a steel indenter with a $2.5 \mathrm{~mm}$ diameter (HB10 scale).

Microstructural analyses were carried out by Optical Microscopy (OM) and Scanning Electron Microscopy equipped with Energy Dispersive X-ray Spectroscopy (Evo-50 SEM: Zeiss, Oberkochen, Germany) on prepared specimens. Metallographic preparation was performed by chemical etching the grinded and polished specimens with $0.5 \%$ HF solution.

Over aging behaviour of the alloy was evaluated by subjecting $\mathrm{T} 6^{*}$ treated samples to soaking at 200,245 , and $290{ }^{\circ} \mathrm{C}$ for times ranging from $10 \mathrm{~min}$ to $168 \mathrm{~h}$. After extraction from the furnace at prefixed times, hardness measurements were carried out (by calculating the average of at least five measurements for each condition), which allows the provision of the over aging curves. This also represents the variation of hardness with soaking time at the different temperatures. A comparison with an A356-T6 over aging curve at $200{ }^{\circ} \mathrm{C}$ was also carried out. The A356 is one of the most widely used Al-Si-Mg alloy for cast engine components.

\subsection{Mechanical Characterization}

Round dog-bone tensile specimens $\left(L_{0}=25 \mathrm{~mm}\right.$, gauge diameter $\left.d_{0}=5 \mathrm{~mm}\right)$ were machined from A354 cast ingots subjected to Hot Isostatic Pressing (HIP) to eliminate internal porosity. Tensile specimens were then heat treated, according to the optimized treatment parameters (T6*). Some of them were also over-aged for $50 \mathrm{~h}$ at $210{ }^{\circ} \mathrm{C}$. Both $\mathrm{T} 6^{*}$ and over-aged samples were subjected to tensile tests carried out at room temperature on a servo-hydraulic testing machine, according to Reference [14]. For each investigated condition, three specimens were tested. Tensile properties were derived from the data acquisition system and calculated as the average of the three tested samples. The mechanical behavior of the A354-T6* alloy was compared both to that of the A354 alloy heat treated sample, according to an industrial practice treatment, which is hereafter referred to as A354-T6 (solution treatment at $515^{\circ} \mathrm{C}$ for $10 \mathrm{~h}$, quench in water at $60^{\circ} \mathrm{C}$ and artificial aging at $210{ }^{\circ} \mathrm{C}$ for $6 \mathrm{~h}$ ) and to the T6 heat treated C355 (AlSi5Cu1Mg0.5) alloy (solution treatment at $530{ }^{\circ} \mathrm{C}$ for $24 \mathrm{~h}$, quench in water at $60{ }^{\circ} \mathrm{C}$ and artificial aging at $180{ }^{\circ} \mathrm{C}$ for $6 \mathrm{~h}$ ). For comparison, tensile data of A354-T6 and C355-T6 alloys refer to samples characterized by similar SDAS values ( 20-25 $\mu \mathrm{m})$ and similarly obtained from HIPped castings. For A354-T6 and C355-T6 alloys, the over aging condition was set to $41 \mathrm{~h}$ at $210{ }^{\circ} \mathrm{C}$. A detailed microstructural and mechanical characterization for such alloys can be found elsewhere [8,9]. Fractographic analyses were carried out on tensile fracture surfaces by means of SEM-EDS, which aim to assess the mechanisms of failure. 


\section{Results and Discussion}

\subsection{Heat Treatment Optimization}

\section{(i) Solution Treatment Optimization-1st Stage}

The microstructure of the as-cast A354 alloy consists of $\alpha$-Al dendrites surrounded by eutectic silicon particles (Figure 1a). The average SDAS value of the as-cast alloy calculated by image analyses on optical micrographs was equal to $25 \pm 3 \mu \mathrm{m}$, which corresponds to the typical value of permanent mold gravity products. The effect of chemical modification by Sr addition is reflected in the morphology of eutectic silicon particles, which are mostly fibrous and well modified (Figure 1b) and are characterized by an average aspect ratio of 2.3. Some irregular particles at the interface with the $\alpha$-Al matrix were also observed (Figure 1b, black arrows), as a possible result of back diffusion during the cooling from the dendrites to the pre-existing Si particles, which was previously reported by Sjölander [15]. Several intermetallic phases were found in the interdendritic regions (Figure 1b, white arrows) whose chemical composition was investigated through SEM-EDS (Figure 2).
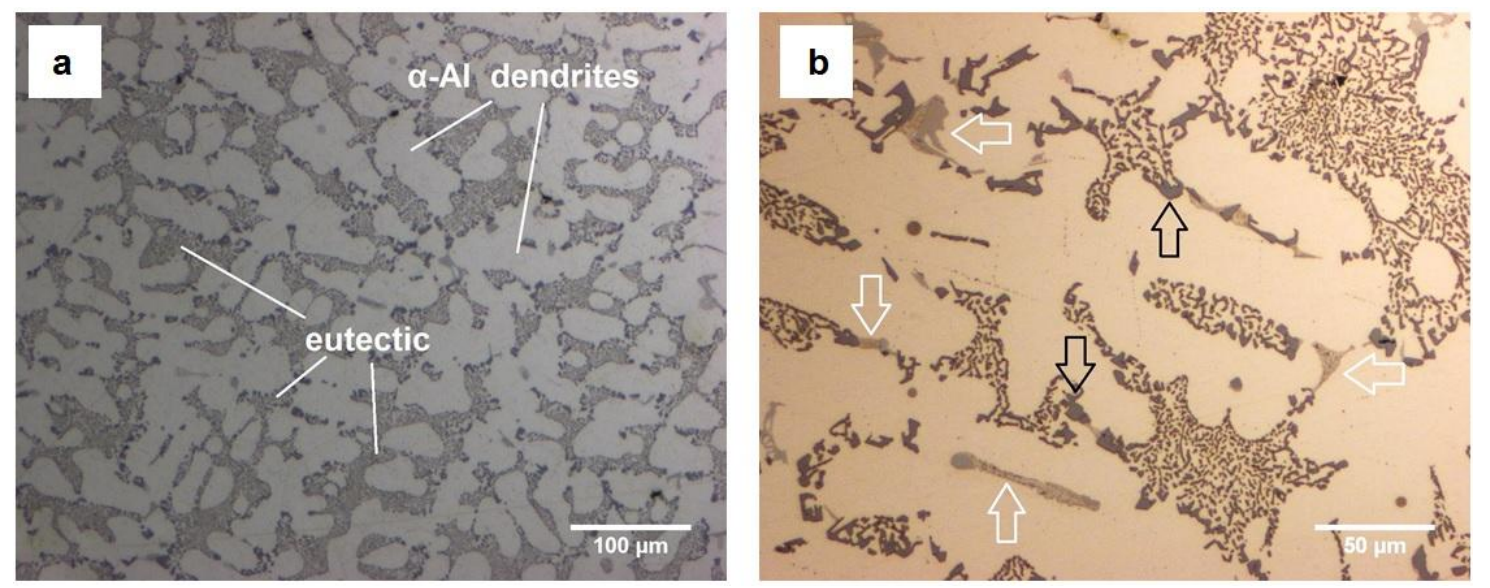

Figure 1. Optical micrographs of the as cast A354 alloy: (a) dendritic structure surrounded by eutectic silicon particles and (b) higher magnification image showing coarse intermetallics formed during solidification (white arrows) and eutectic Si particles, partially unmodified (black arrows).

The most common intermetallic phase identified in the as-cast microstructure was the $\theta-\mathrm{Al}_{2} \mathrm{Cu}$ present in two different morphologies including blocky (indicated as $\theta_{\mathrm{b}}$, Figure 2a) or eutectic (indicated as $\theta_{\mathrm{e}}$, Figure 2b) [16,17]. Quaternary Q particles were also identified and appear as regular blocks characterized by smooth borders (Figure 2a). Q particles, characterized by a chemical composition consistent with the most widely accepted one, i.e., $\mathrm{Al}_{5} \mathrm{Cu}_{2} \mathrm{Mg}_{8} \mathrm{Si}_{6}$ [3,17-19], were often observed in combination with $\theta-\mathrm{Al}_{2} \mathrm{Cu}$ phases (Figure $2 \mathrm{c}$ ). This occurrence should be ascribed to the fact that these phases are formed during the final eutectic reaction during solidification [3,17]. Differential thermal analyses (DTA) carried out on the as-cast material revealed a low melting compound (Figure 3a), which was characterized by the onset of the reaction at $\sim 507{ }^{\circ} \mathrm{C}$ and peak at $\sim 509{ }^{\circ} \mathrm{C}$ (Figure 3b). The corresponding reaction should be ascribed to the following transformation $[1,20]$.

$$
\alpha(\mathrm{Al})+\mathrm{Al}_{2} \mathrm{Cu}+\mathrm{Si}+\mathrm{Al}_{5} \mathrm{Cu}_{2} \mathrm{Mg}_{8} \mathrm{Si}_{6} \rightarrow \mathrm{L}
$$




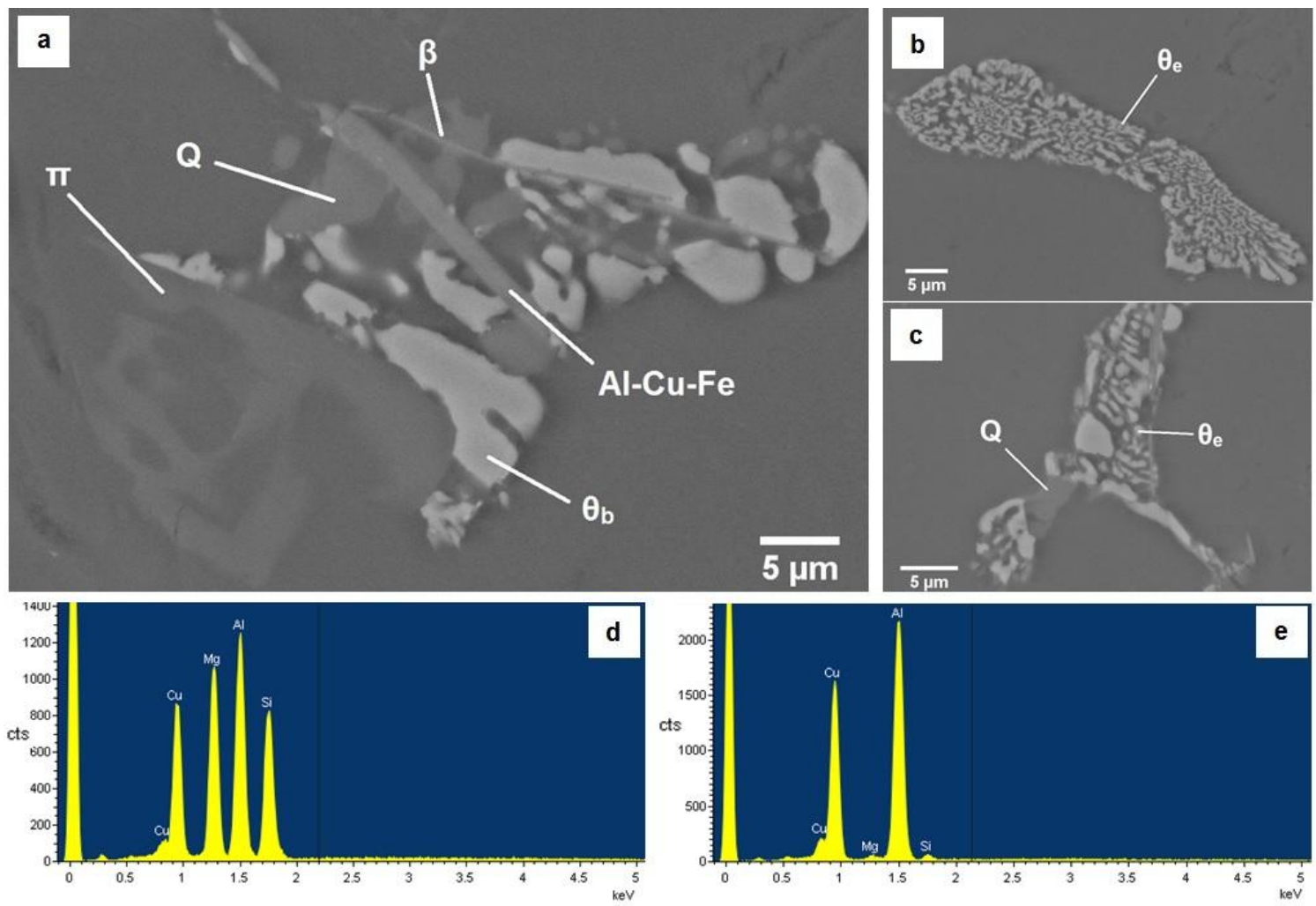

Figure 2. SEM images of typical intermetallic particles observed in the A354 as cast alloy: (a) different Cu-based intermetallics (blocky $\theta-\mathrm{Al}_{2} \mathrm{Cu}$, indicated as $\theta_{\mathrm{b}}$ and $\mathrm{Q}$ ) and Fe-based particles $\left(\beta-\mathrm{Al}_{5} \mathrm{FeSi}\right.$, $\pi-\mathrm{Al}_{8} \mathrm{Mg}_{3} \mathrm{FeSi}_{6}$ ). (b) $\theta-\mathrm{Al}_{2} \mathrm{Cu}$ phase with eutectic morphology indicated as $\theta_{\mathrm{e}}$. (c) $\theta-\mathrm{Al}_{2} \mathrm{Cu}$ phase associated with the $Q$ phase. EDS spectra of (d) $Q$ and (e) $\theta$ phases in Figure $2 c$ and readapted from Reference [21].
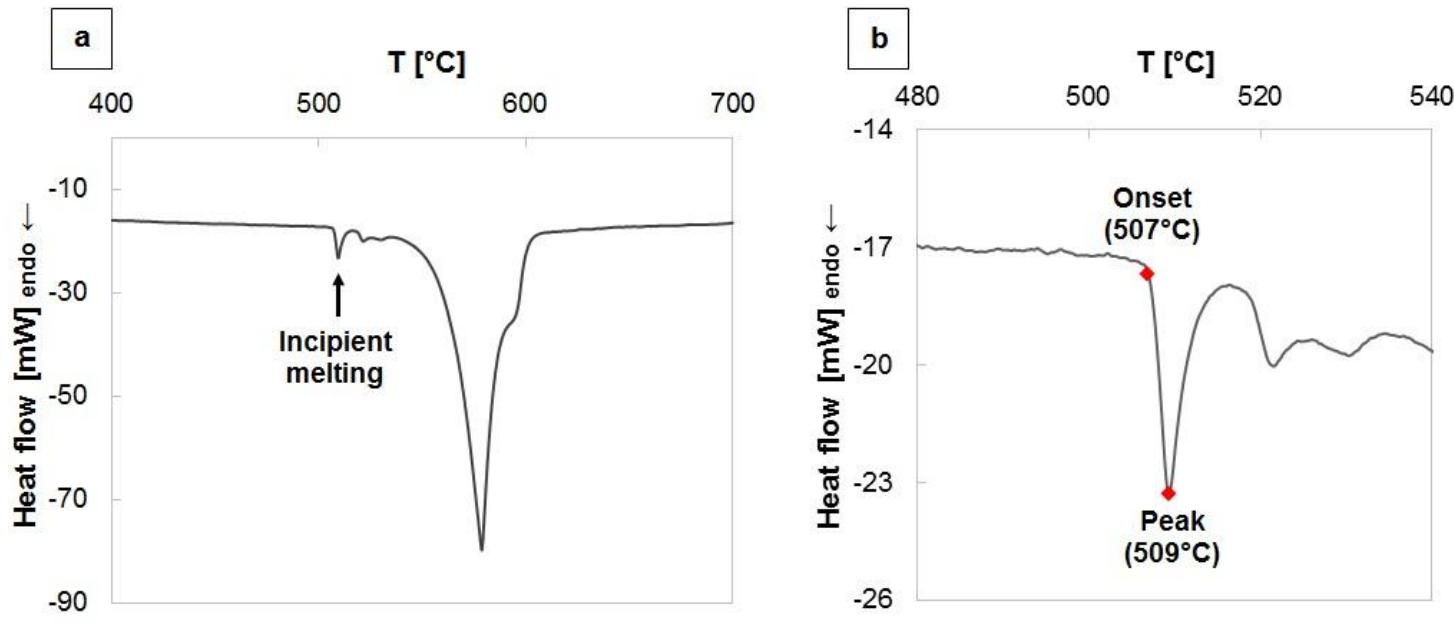

Figure 3. Differential thermal analyses (DTA) carried out on the as-cast A354 alloy, (a) highlighting the presence of a low melting compound at $509{ }^{\circ} \mathrm{C}$. (b) The incipient melting reaction readapted from Reference [21].

The presence of a low melting phase is widely reported for high $\mathrm{Cu}$ content alloys (>2 wt.\%) [12,22,23] while low $\mathrm{Cu}$ alloys are not always observed to present this endothermic peak [22]. In spite of this, a first low-temperature solution stage is indicated by some authors for such alloys, which is consistent with the presence of the mentioned peak $[19,24,25]$. The maximum affordable solution temperature depends on alloy specific composition and the solidification rate influencing microstructural fineness 
and segregation of intermetallic phases [26]. Experimental results of the present work suggest not to exceed during the solution heat treatment of the investigated alloy, the onset temperature of reaction (1), which aims to avoid incipient melting of the casting. A double stage solution treatment was, therefore, adopted. The first stage aimed to dissolve the low melting phase and the second one to maximize the dissolution of alloying elements (i.e., $\mathrm{Cu}$ and $\mathrm{Mg}$ ) in the $\alpha$ - $\mathrm{Al}$, which makes them available for precipitation hardening during artificial aging. On the basis of DTA results, the first stage temperature was set to $495^{\circ} \mathrm{C}$.

In order to determine the needed time to dissolve the low melting phase, several A354 cast samples were subjected to solution heat treatment at $495^{\circ} \mathrm{C}$ from $30 \mathrm{~min}$ to $6 \mathrm{~h}$ and then to differential thermal analyses. Thermal diagrams, reported in Figure 4, show that the endothermic peak at $509{ }^{\circ} \mathrm{C}$ remains unmodified after 30 min of solution treatment while gradually diminishing its amplitude after 4 and $5 \mathrm{~h}$ of treatment. After $6 \mathrm{~h}$ at $495^{\circ} \mathrm{C}$, the peak disappears.

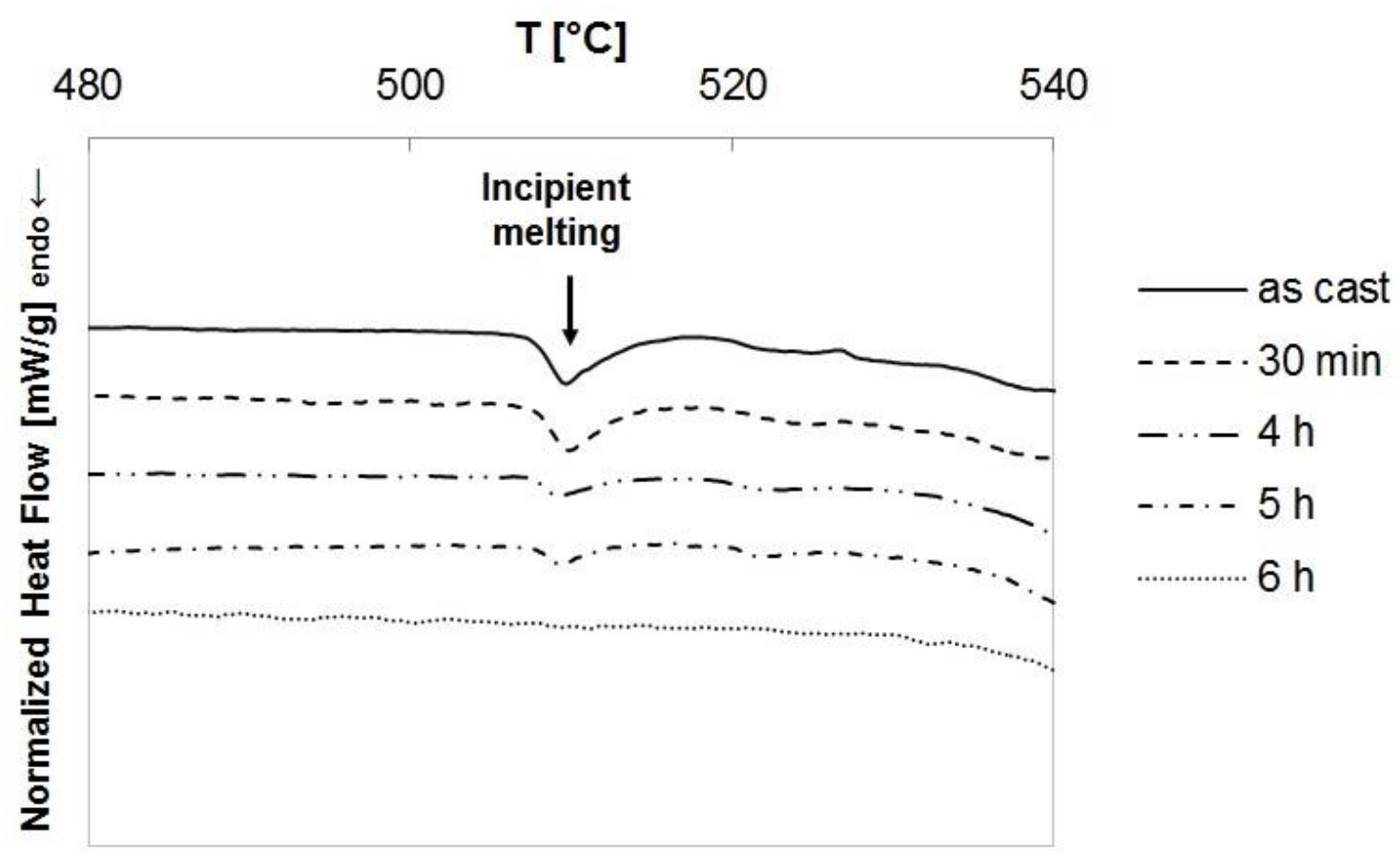

Figure 4. Differential thermal analyses (DTA) carried out on A354 samples solution treated at $495^{\circ} \mathrm{C}$ for $30 \mathrm{~min}, 4,5$, and $6 \mathrm{~h}$ (from room temperature to $700^{\circ} \mathrm{C}$ in Ar gas, heating rate $10^{\circ} \mathrm{C} / \mathrm{min}$ ), which shows the dissolution of the low melting phase after $6 \mathrm{~h}$. This was readapted from Reference [21].

It is, therefore, inferred that a first $6 \mathrm{~h}$ solution stage at $495^{\circ} \mathrm{C}$ is needed to take into the solution the quaternary eutectic, allowing to subject the alloy to a second solution stage at a higher temperature. Optical micrographs of samples solution treated at $495^{\circ} \mathrm{C}$ for 2 and $6 \mathrm{~h}$ are reported in Figure 5a,b, respectively. While $\theta-\mathrm{Al}_{2} \mathrm{Cu}$ particles after $2 \mathrm{~h}$ of treatment are unmodified if compared to the as-cast microstructure (Figure 5a), they undergo fragmentation and almost completely dissolve after $6 \mathrm{~h}$ of treatment. Some $\mathrm{Al}_{2} \mathrm{Cu}$ particles partially undissolved were still observed (Figure 5c, white arrow). This observation was confirmed by SEM-EDS analyses. After $6 \mathrm{~h}$, in particular, only negligible traces of eutectic $\mathrm{Al}_{2} \mathrm{Cu}$ were found with small blocky $\theta$ particles (Figure $5 \mathrm{~d}$ ). The different dissolution behavior between eutectic and blocky particles was observed in the study of Han et al. [17] who argued that, due to the shape of the particles, dissolution of eutectic $\mathrm{Al}_{2} \mathrm{Cu}$ goes on by necking of the intermetallic in several points of the particle length, successive breaking into smaller fragments, and final spherodization/dissolution. Blocky phases, on the contrary, undergo gradual dissolution of the entire particle. Therefore, this requires higher times and temperatures for complete dissolution. 

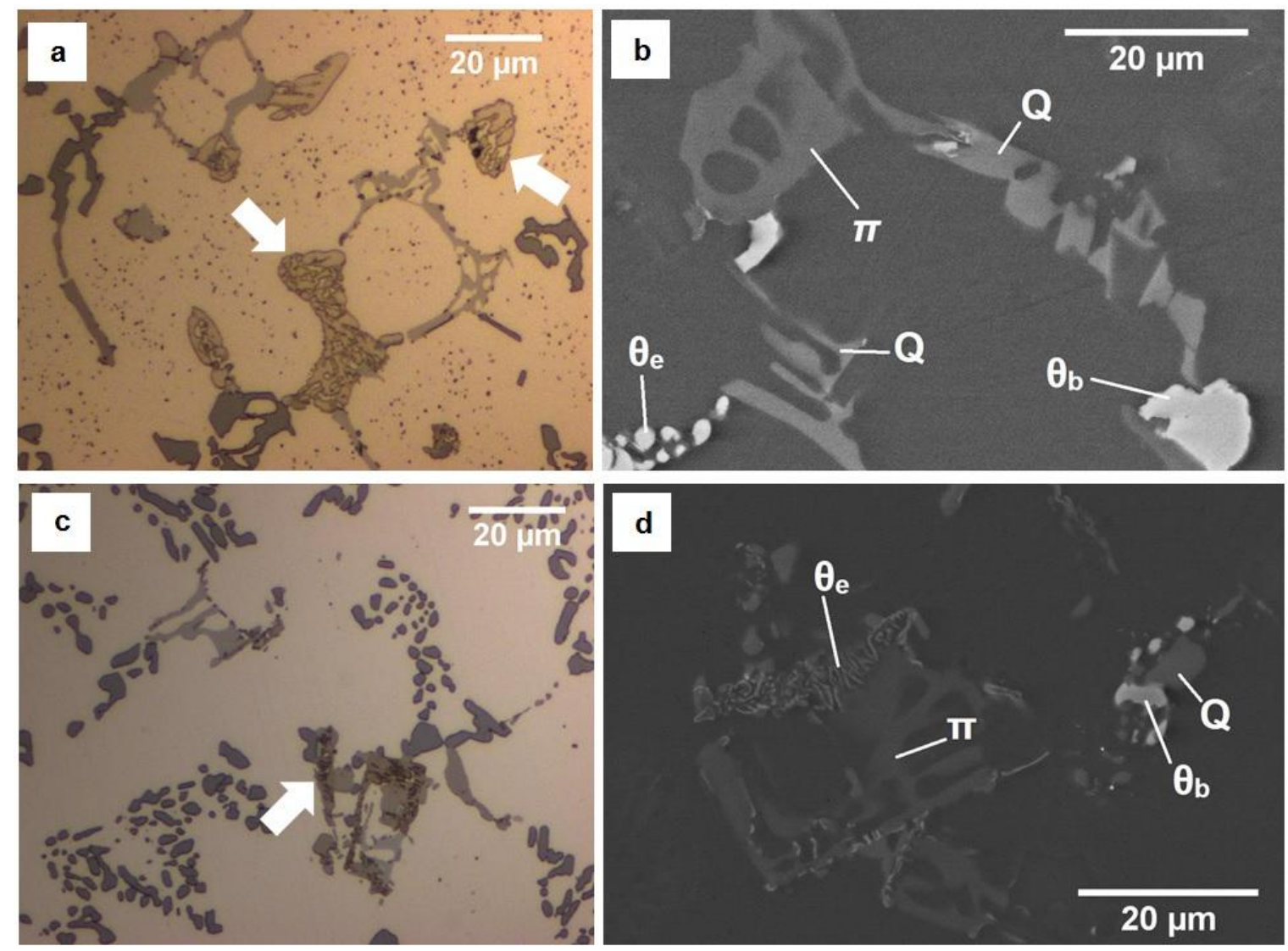

Figure 5. Optical and SEM images of A354 samples solution heat treated at $495{ }^{\circ} \mathrm{C}$ for $(\mathbf{a}, \mathbf{b}) 2 \mathrm{~h}$ and $(\mathbf{c}, \mathrm{d}) 6 \mathrm{~h}$, show the different dissolution behavior of eutectic $\left(\theta_{\mathrm{e}}\right)$ and block-like $\left(\theta_{\mathrm{b}}\right) \mathrm{Al}_{2} \mathrm{Cu}$ particles; partially readapted from Reference [21].

Both $\pi$-Fe and Q phases were observed after the first solution stage. The tendency of $Q$ phases to dissolve or not is reported to be strongly dependent on microstructural coarseness: Sjölander [15] observed a decrease in the area fraction of $\mathrm{Q}$ phases after $3 \mathrm{~h}$ of solution at $495^{\circ} \mathrm{C}$ for an $\mathrm{Al}-\mathrm{Si}-\mathrm{Cu}-\mathrm{Mg}$ alloy with $3 \mathrm{wt} . \% \mathrm{Cu}$ characterized by $9 \mu \mathrm{m}$ SDAS while no variation in the area fraction covered by $Q$ particles was observed in coarser microstructures (24 and $49 \mu \mathrm{m}$ SDAS, respectively). In general, however, there is controversy in literature about its stability [17,19,22,27-30]. Different studies reported the $\mathrm{Q}$ phase to be completely dissolved and partially or completely undissolved depending on several factors such as: chemical composition ( $\mathrm{Cu} / \mathrm{Mg}$ ratio), solution parameters (time/temperature), thermodynamic stability and kinetics of dissolution. In the present investigation, where $\mathrm{Cu} / \mathrm{Mg}$ is $\sim 3.7$, no remarkable dissolution of $Q$ particles was registered after the first solution stage at $495{ }^{\circ} \mathrm{C}$.

\section{(ii) Solution Treatment Optimization-2nd Stage}

In view of the previous analyses, a new set of A354 samples was solution treated at $495^{\circ} \mathrm{C}$ for $6 \mathrm{~h}$, then to a second solution stage, at 515 or $530^{\circ} \mathrm{C}$ for times ranging from 2 to $8 \mathrm{~h}$. SEM-EDS analyses on treated samples allowed to observe that, after $2 \mathrm{~h}$ at the lowest temperature (i.e., $515^{\circ} \mathrm{C}$ ), only a very small amount of $\mathrm{Al}_{2} \mathrm{Cu}$ particles remained, as a result of dissolution of both eutectic and blocky particles (Figure 6a). The size of remaining $\mathrm{Al}_{2} \mathrm{Cu}$ particles, however, was generally even too small (less than $1 \mu \mathrm{m}$ ) for clear identification by EDS analyses. Same findings were reported by observing samples treated at $515^{\circ} \mathrm{C}$ for longer solution times. No relevant difference between samples treated at $530^{\circ} \mathrm{C}$ and $515{ }^{\circ} \mathrm{C}$ was appreciated by SEM in terms of $\mathrm{Al}_{2} \mathrm{Cu}$ particles dissolution. 

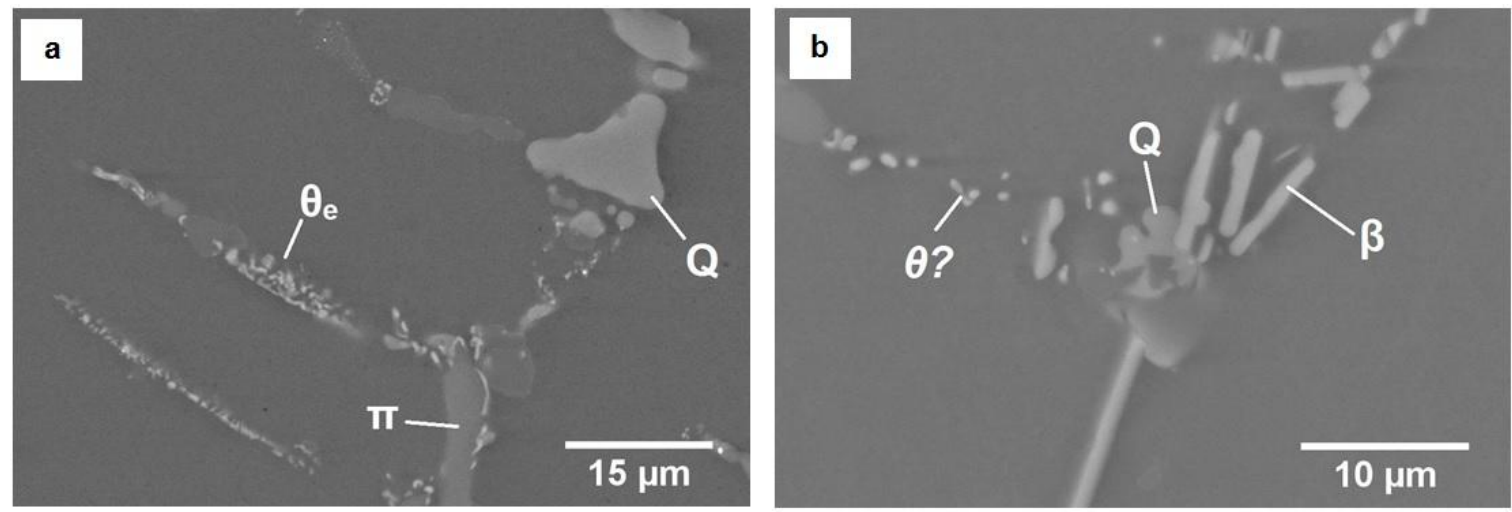

Figure 6. SEM images of A354 samples subjected to double stage solution treatment: $495{ }^{\circ} \mathrm{C}-6 \mathrm{~h}$, then $515^{\circ} \mathrm{C}-2 \mathrm{~h}(\mathbf{a})$, and $530{ }^{\circ} \mathrm{C}-8 \mathrm{~h}(\mathbf{b})$, which is readapted from Reference [21].

Regarding other $\mathrm{Cu} / \mathrm{Mg}$ bearing phases such as $\pi$-Fe and $\mathrm{Q}$ particles, it was observed that (i) $\pi$-Fe were apparently unaffected by high temperature solution treatment since they remained present also after solution treatment at $530{ }^{\circ} \mathrm{C}$ for $6 \mathrm{~h}$. (ii) $\mathrm{Q}$ phases were still observed, even if characterized by decreasing average size, because of partial dissolution induced by a high temperature solution treatment. The persistence of $\pi$-Fe after solution treatment is generally well documented and observed by different authors such as Taylor et al. and Mbuya et al. [31-33]. A complete particles dissolution is thought to be unlikely due to the low solid solubility of $\mathrm{Fe}$ in the $\mathrm{Al}$ matrix. Nevertheless, transformation of iron intermetallics from one phase to another, partial fragmentation, or spherodization is also reported [31-34]. A slight variation in $\beta$-Fe needles morphology was observed especially in samples solution treated at $530^{\circ} \mathrm{C}$, which are Fe-based particles characterized by rounded edges (Figure 6b). Dissolution phenomena induced by a high temperature solution treatment may have contributed to this occurrence. Concerning $Q$ particles from experimental data, it is possible to affirm that, at the considered solution treatment conditions and for an alloy characterized by $1.7 \mathrm{wt} . \% \mathrm{Cu}$ and $\sim 3.7 \mathrm{Cu} / \mathrm{Mg}$ ratio, the $\mathrm{Q}$ phase was only partially dissolved by solution treatment. The evolution of the average area fraction of intermetallics particles (IM), calculated on SEM images, well reflects this scenario (Figure 7). The IM area fraction remarkably decreases from $1.30 \%$ in the as-cast condition to $0.88 \%$ after $6 \mathrm{~h}$ at $495{ }^{\circ} \mathrm{C}$ due to the dissolution of $\theta-\mathrm{Al}_{2} \mathrm{Cu}$ phase. By increasing the solution temperature to $515^{\circ} \mathrm{C}$ and $530^{\circ} \mathrm{C}$, a further, limited decrease of intermetallics fraction was registered up to the minimum value of $\mathrm{IM}=0.61 \%$ after $8 \mathrm{~h}$ at $530^{\circ} \mathrm{C}$ due to the partial dissolution of the $\mathrm{Q}$ phase.

Hardness of the alloy was evaluated after solutioning at $515{ }^{\circ} \mathrm{C}$ and $530{ }^{\circ} \mathrm{C}$, quenching and artificial aging at a fixed condition including $200{ }^{\circ} \mathrm{C}$ for $2 \mathrm{~h}$ (Figure 8) in order to define the treatment condition enabling the maximum increase of mechanical strength after aging while maintaining the solution temperature and time as low as possible. The as-cast alloy presented a hardness of $79 \mathrm{HB}$, which remarkably increased after the first solution stage $\left(495^{\circ} \mathrm{C}-6 \mathrm{~h}\right)$ and aging, to $115 \mathrm{HB}$, thanks to $\mathrm{Cu}$ made available by dissolution of $\theta-\mathrm{Al}_{2} \mathrm{Cu}$. By the second stage solution treatment (at $515^{\circ} \mathrm{C}$ or $530{ }^{\circ} \mathrm{C}$ ), a further hardness increase was observed in all the investigated conditions due to the further dissolution of $\mathrm{Cu} / \mathrm{Mg}$, which strengthens precipitates during subsequent artificial aging. No remarkable difference was registered in the hardness of samples solution treated at $515{ }^{\circ} \mathrm{C}$ and $530{ }^{\circ} \mathrm{C}$, which reflects no appreciable microstructural variations observed by SEM. From this experimental study, it is, therefore, possible to affirm that the different double stage solution conditions lead to similar hardness values ranging from 130 to $135 \mathrm{HB}$. In view of this, in order to keep the treatment cost-effective, the lowest temperature and time (namely $515{ }^{\circ} \mathrm{C}-2 \mathrm{~h}$ ) were chosen for optimization of the second stage solution treatment. 


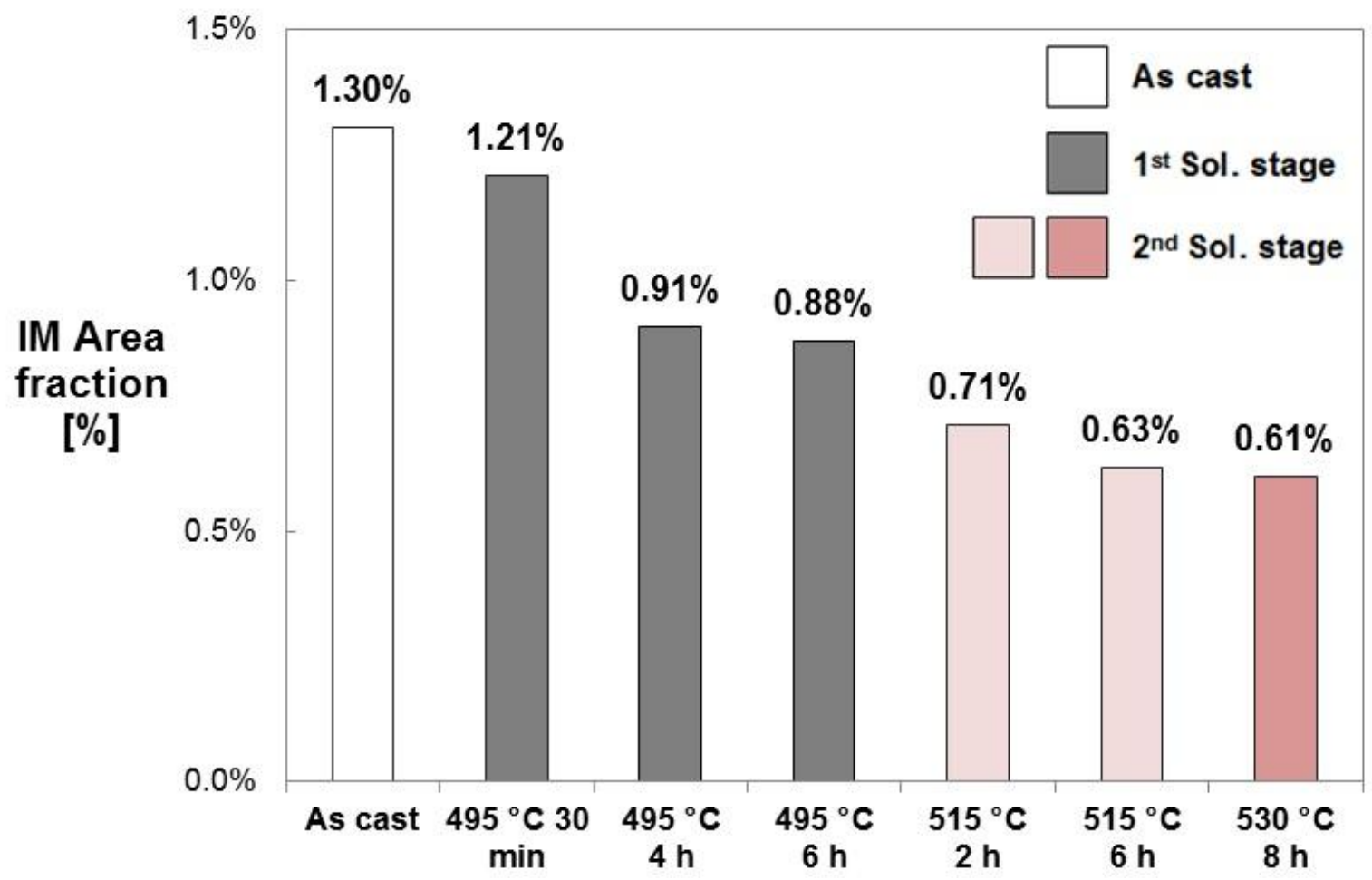

Figure 7. Average area fraction of intermetallics (IM) [\%] calculated by SEM image analyses on A354 samples in different heat treatment conditions (as-cast, after the first solution stage at $495^{\circ} \mathrm{C}$, and after different second solution stages at $515 / 530^{\circ} \mathrm{C}$ ). This is re-adapted from Reference [21].

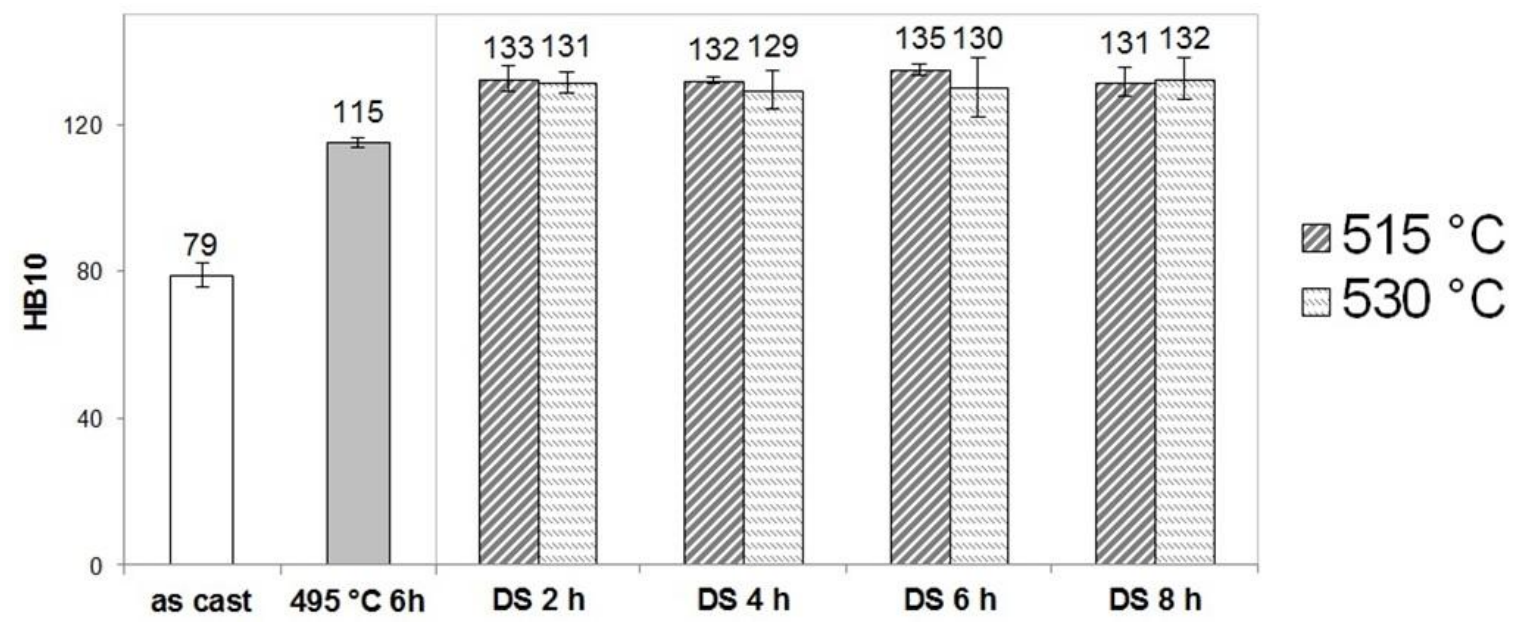

Figure 8. Hardness of A354 alloy in the as-cast condition, after solution treatment at $495{ }^{\circ} \mathrm{C}-6 \mathrm{~h}$, and after Double Stage (DS) solution at $495^{\circ} \mathrm{C}-6 \mathrm{~h}+515 / 530^{\circ} \mathrm{C}-2 / 8 \mathrm{~h}$, which is followed by hot water quenching $\left(60^{\circ} \mathrm{C}\right)$ and artificial aging at $200{ }^{\circ} \mathrm{C}-2 \mathrm{~h}$. This is readapted from Reference [21].

(iii) Artificial Aging Optimization

Figure 9 shows aging curves of A354 alloy obtained by evaluating the evolution of Brinell hardness by aging the alloy at $160,180,190,200$, and $210^{\circ} \mathrm{C}$ for times up to $48 \mathrm{~h}$ after the optimized solution treatment $\left(495^{\circ} \mathrm{C}-6 \mathrm{~h}+515^{\circ} \mathrm{C}-2 \mathrm{~h}\right)$, which is followed by water quenching $\left(60^{\circ} \mathrm{C}\right)$ [21]. Despite that the aging behavior of ternary $\mathrm{Al}-\mathrm{Si}-\mathrm{Mg}$ alloys has been widely investigated, the knowledge of age hardening of Al-Si-Cu-Mg alloys is not similarly investigated, probably due to the intrinsic complexity of the precipitation sequence regarding $\beta\left(\mathrm{Mg}_{2} \mathrm{Si}\right), \theta\left(\mathrm{Al}_{2} \mathrm{Cu}\right)$, and $\mathrm{Q}\left(\mathrm{Al}_{5} \mathrm{Cu}_{2} \mathrm{Mg}_{8} \mathrm{Si}_{6}\right)$ phases. Observing the A354 aging curves in Figure 9, it is clear that the aging temperature plays an important role on 
precipitation hardening. Similarly to what has been observed by other studies, by increasing the aging temperature, the time required to reach the peak is reduced $[24,35]$ and, with the exception of $160{ }^{\circ} \mathrm{C}$, the peak hardness is generally reduced [30,36,37]. At $160{ }^{\circ} \mathrm{C}$ aging temperature, the lowest investigated temperature, a slow initial hardness increase from the as cast condition is registered as a result of the low rate of atomic diffusion related to this temperature. At $160{ }^{\circ} \mathrm{C}$, the peak hardness $(\sim 133 \mathrm{HB})$ is reached after $18 \mathrm{~h}$. At higher aging temperatures, i.e., $180^{\circ} \mathrm{C}$ and $190{ }^{\circ} \mathrm{C}$, precipitation kinetics are faster and result in a shorter time to peak hardness, which is similar for both temperatures $(\sim 136 \mathrm{HB})$ reached after 6 and $4 \mathrm{~h}$ of aging at $180{ }^{\circ} \mathrm{C}$ and $190{ }^{\circ} \mathrm{C}$, respectively. Correspondingly, an increase of the initial slope of the curves occurred by raising the aging temperature from $160^{\circ} \mathrm{C}$ to $180-200^{\circ} \mathrm{C}$. By further increasing the aging temperature, diffusion mechanisms are further accelerated, which results in a remarkably steep initial slope at $210^{\circ} \mathrm{C}$. In this condition, the time to peak hardness ( $\sim 135 \mathrm{HB})$ is clearly decreased ( $\sim 90 \mathrm{~min})$. The aging temperature influences the hardness evolution after the peak condition. At the lowest temperatures $\left(160^{\circ} \mathrm{C}\right.$ and $\left.180^{\circ} \mathrm{C}\right)$, once the peak is reached, the alloy hardness reaches a plateau, which remains basically constant.
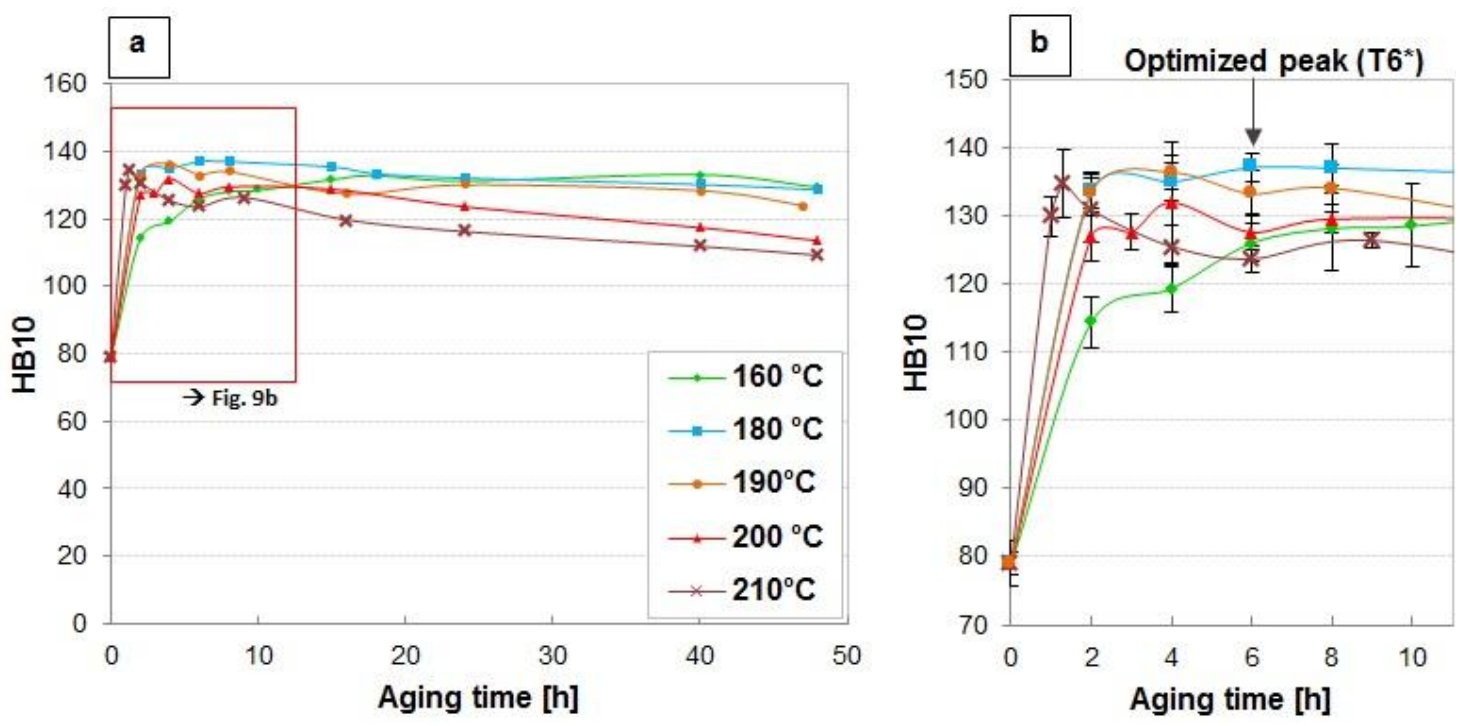

Figure 9. Aging curves of A354 alloy show the evolution of Brinell hardness with aging time. The samples were solution treated at $495{ }^{\circ} \mathrm{C}-6 \mathrm{~h}$, then $515{ }^{\circ} \mathrm{C}-2 \mathrm{~h}$, water quenched $\left(60{ }^{\circ} \mathrm{C}\right)$ and aged at $160,180,190,200$, and $210{ }^{\circ} \mathrm{C}$ for up to $48 \mathrm{~h}$, (a) Focus on the first aging hours (b). This is readapted from Reference [21].

On the other hand, at higher temperatures $\left(190-210{ }^{\circ} \mathrm{C}\right)$, once the peak is reached, hardness decreases. At $210{ }^{\circ} \mathrm{C}$, a remarkable loss of hardness (about $10 \mathrm{HB}$ ) was registered $2 \mathrm{~h}$ after the peak condition. Such a hardness decrease should be ascribed to the over aging phenomenon, which involves coarsening of strengthening precipitates (Ostwald ripening) at the expenses of smaller ones [38,39]. In addition, the presence of double aging peaks is reported in the literature for temperatures higher than $175^{\circ} \mathrm{C}$. This behavior, reported by Li et al. [36], in an alloy with similar composition was related by the authors to the precipitation sequence in particular for the formation of GP zones and metastable particles, respectively. In the current investigation, no clear evidence of this phenomenon was observed. On the basis of the experimental data, the highest hardness value, $136 \mathrm{HB}$, is reached by aging at $180^{\circ} \mathrm{C}$ and $190^{\circ} \mathrm{C}$ for 6 and $4 \mathrm{~h}$, respectively. Despite aging to the peak at $190^{\circ} \mathrm{C}$ would require less time ( $4 \mathrm{~h}$ vs. $6 \mathrm{~h}$ ), it was preferred to age at the lowest temperature, $180^{\circ} \mathrm{C}$, aiming to prevent from over aging, which occurred after the peak at $190^{\circ} \mathrm{C}$. 


\subsection{Overaging of the A354-T6 Alloy}

Figure 10 shows the over aging curves of A354-T6* alloy, which are meant to assess the loss of hardness from the peak condition because of exposure at temperatures higher than the peak aging one $\left(200,245\right.$, and $\left.290^{\circ} \mathrm{C}\right)$. At $200^{\circ} \mathrm{C}$, close to the aging temperature $\left(180^{\circ} \mathrm{C}\right)$, the loss of hardness is gradual; after $168 \mathrm{~h}$ at $200{ }^{\circ} \mathrm{C}$, a decrease of $25 \%$ hardness with respect to the peak aging condition $(136 \mathrm{HB})$ was registered. For comparison, the $200{ }^{\circ} \mathrm{C}$ over aging curve of the A356-T6 ternary (Al-Si-Mg) alloy is plotted. It is interesting to note that the two alloys present a remarkably different behavior. While the A354 alloy maintains a certain stability after $48 \mathrm{~h}$ of over aging with a hardness decrease of about $15 \%$, A356 underwent a more consistent hardness loss, of about $35 \%$. After 7 days soaking at $200{ }^{\circ} \mathrm{C}$, hardness of the A356 further decreases to the minimum value of $52 \mathrm{HB}$, corresponding to a loss of $52 \%$ with respect to the initial value. In the same condition, A354 is still characterized by $102 \mathrm{HB}$, which corresponds to a $25 \%$ decrease with respect to the peak condition.

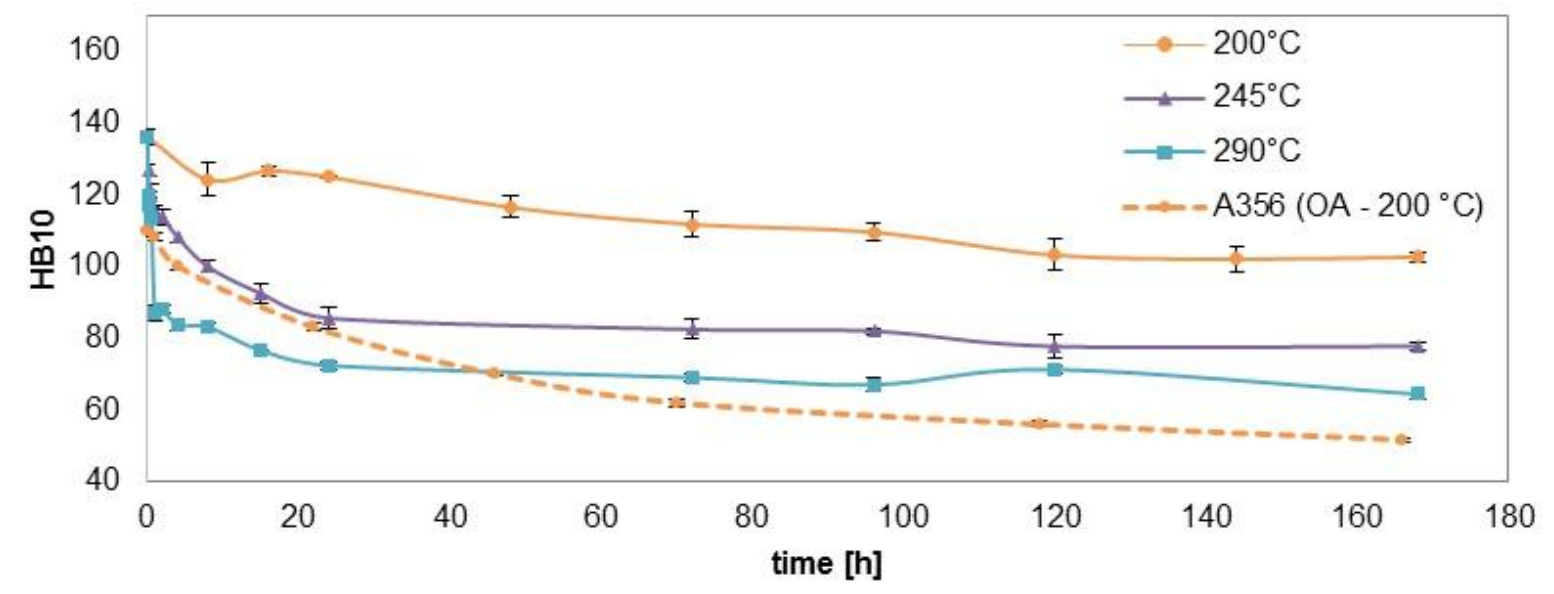

Figure 10. Over aging curves of the A354-T6* alloy carried out at 200, 245, and $290^{\circ} \mathrm{C}$. For comparison, the curve of A356-T6 alloy overaged at $200{ }^{\circ} \mathrm{C}$ is also presented. The data is from Reference [21].

This confirms the beneficial effect of $\mathrm{Cu}$ addition on the thermal resistance of Al-Si-Mg alloys: as recently investigated by Farkoosh et al. [7], the presence of $\mathrm{Cu}$ induces the formation of quaternary $\mathrm{Q}$ precipitates. Such phases were reported by the authors to be the only age-hardening phases remaining stable after soaking the investigated $\mathrm{Al}-7 \mathrm{Si}-0.5 \mathrm{Cu}-\mathrm{Mg}$ alloy at $300^{\circ} \mathrm{C}$ for $100 \mathrm{~h}$, while $\theta-\mathrm{Al}_{2} \mathrm{Cu}$ precipitates are dissolved due to their thermodynamic instability at this temperature $[7,40]$. At higher over aging temperatures, kinetics of diffusion is enhanced and a more pronounced hardness drop is registered in the first $10 \mathrm{~h}$ of high temperature soaking, especially by over aging at $290^{\circ} \mathrm{C}$. At both these temperatures, after $\sim 24 \mathrm{~h}$, the hardness reaches a sort of plateau, which is basically maintained for increasing exposure times. After soaking at 245 and $290{ }^{\circ} \mathrm{C}$ for $168 \mathrm{~h}$, a decrease of hardness of $42 \%$ and $53 \%$ was registered with respect to the peak condition, respectively. After $168 \mathrm{~h}$ at $200{ }^{\circ} \mathrm{C}$, the hardness value registered for A356 alloy (equal to $52 \mathrm{HB}$ ) is lower than the residual hardness of the A354 alloy subjected to over aging at $290^{\circ} \mathrm{C}$ for equal time $(64 \mathrm{HB})$, as a further confirmation of the superior resistance of quaternary alloys to long-term exposure at a high temperature.

\subsection{Mechanical Characterization}

The results of tensile characterization of A354-T6* alloy are summarized in Figures 11 and 12 where ultimate tensile strength (UTS), yield strength (YS), and elongation to failure (E\%) are compared to those of the same alloy heat treated according to industrial practice (A354-T6) and to the C355 heat treated alloy (C355-T6) [8,9]. With respect to the industrial treatment, an enhancement of tensile properties at room temperature was observed for A354-T6* alloy: UTS and YS increased about 10\% and $5 \%$, respectively. It is thought that this increase was mainly related to the optimization of artificial 
aging phase carried out at $180{ }^{\circ} \mathrm{C}$ for $6 \mathrm{~h}$ while aging treatment of industrial practice $\left(210{ }^{\circ} \mathrm{C}\right.$ for 6 h) likely induced an overaged condition, which is also depicted by the over aging curves obtained in the present study. It is interesting to point out that, in the industrial heat treatment condition, the A354 alloy presented lower UTS and similar YS in comparison to the C355 alloy despite its higher $\mathrm{Cu}$ and $\mathrm{Si}$ contents. An enhanced exploitation of such alloying elements for inducing precipitation hardening through heat treatment was achieved by optimizing the heat treatment. The A354-T6* alloy is characterized by a good level of ductility at room temperature since elongation to failure is about $5 \%$. Nevertheless, being the increase of tensile properties at the expenses of ductility, a slight decrease of elongation to failure was registered for the A354-T6* alloy in comparison to the A354-T6 ( 5\% vs. 6\%). This behavior should be ascribed to the increase in mechanical strength induced by the optimized heat treatment parameters, which is known to be at the expenses of ductility. The lower Si content and higher $\alpha$-Al matrix fraction present in C355 alloy lead, similarly, to an increased elongation to failure, which is about two fold that of the A354 alloy ( 10\% vs. 5\%).

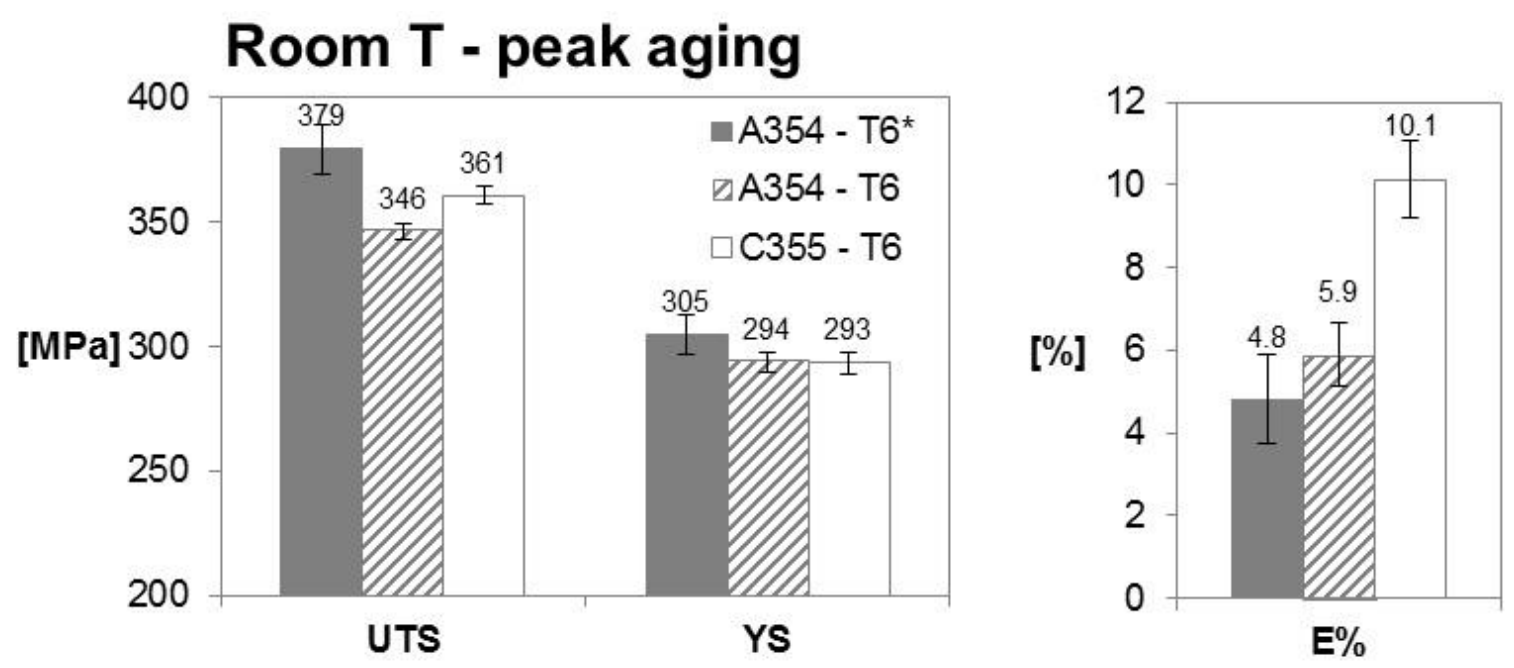

Figure 11. Tensile properties of A354-T6*, A354-T6, and C355-T6 alloys at room temperature in the artificial aging condition, readapted from Reference [21].

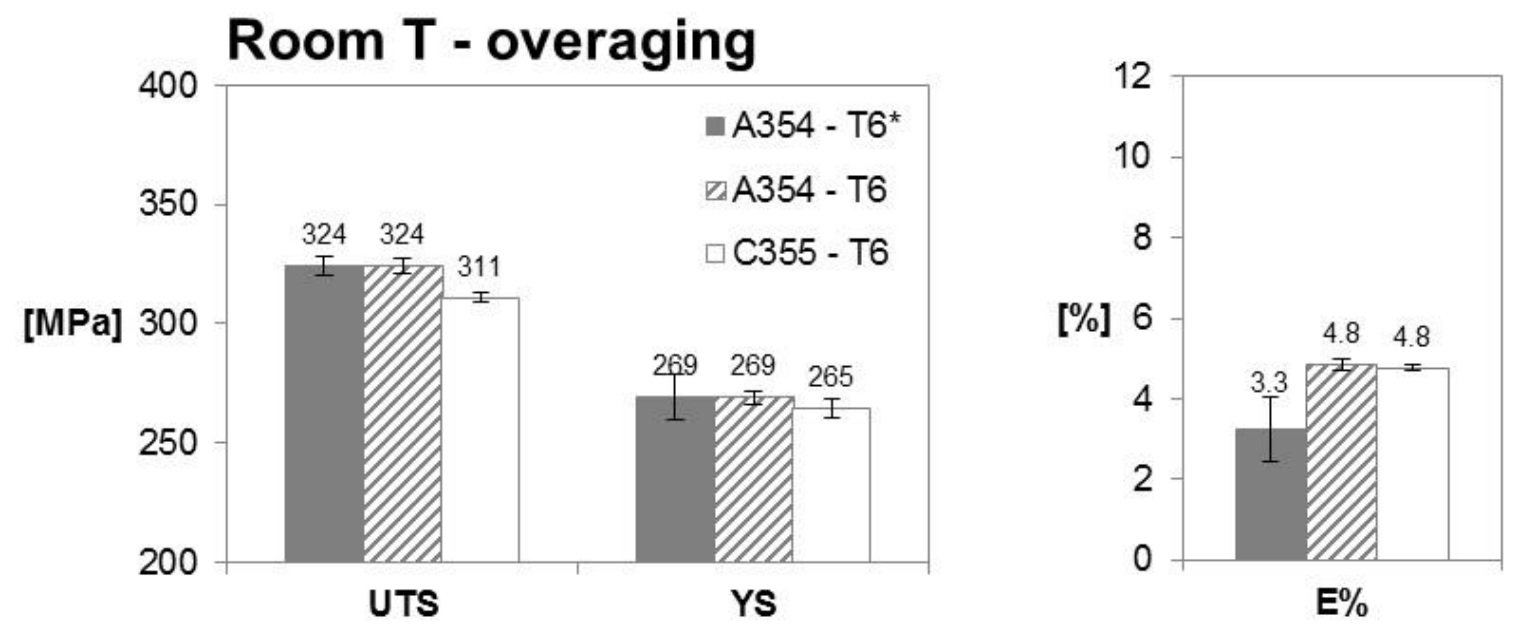

Figure 12. Tensile properties of A354-T6*, A354-T6, and C355-T6 alloys at room temperature in the overaged condition. After heat treatment, the alloys were subjected to soaking at $210{ }^{\circ} \mathrm{C}$ for $50 \mathrm{~h}$ (A354-T6*) and $41 \mathrm{~h}$ (A354-T6 and C355-T6), which is readapted from Reference [21].

The mechanical behavior of the A354 alloy in the overaged condition was investigated in the two different heat treatment practices at equal residual hardness $(\sim 112 \mathrm{HB})$ in order to verify if, 
after a longer high temperature exposure at $210{ }^{\circ} \mathrm{C}$ for A354-T6* alloy (50 h vs. $41 \mathrm{~h}$ for A354-T6* and A354-T6, respectively), similar mechanical properties were maintained. Experimental results showed that, in the optimized heat treatment condition, the A354 alloy maintains the same mechanical properties (UTS = $324 \mathrm{MPa}, \mathrm{YS}=269 \mathrm{MPa}$ ) for longer over-aging duration. Only small differences in elongation to failure were registered between the over-aged A354-T6* and A354-T6 alloys (3.3 vs. $4.8 \%$, respectively). After over-aging, the lower thermal stability of the C355 alloy was assessed in comparison to the A354 alloy independently of the heat treatment condition. It is thought this is due both to the lower $\mathrm{Cu}$ content of the $\mathrm{C} 355$ alloy, which is responsible for the formation of coarsening resistant quaternary precipitates through artificial aging, and to the lower amount of the eutectic Si phase, which contributes to retaining mechanical strength at elevated temperatures and somewhat hindering the plastic flow.

\subsection{Fractographic Analyses}

Representative fracture surfaces of $\mathrm{T} 6^{*}$ and over-aged A354 tensile samples are reported in Figure 13. No noticeable differences in surface morphology was registered between $\mathrm{T} 6^{*}$ and overaged samples, which is characterized by typical ductile appearance. Small-sized and homogeneously distributed dimples developed around Si eutectic particles were observed in both tensile testing conditions as a result of the uniform plastic deformation, which characterizes this kind of microstructure. Fracture mechanisms involved in the deformation process start by cracking the eutectic Si and intermetallic particles due to development of high internal stresses in the particles ascribed to load transfer from the soft $\alpha$-Al matrix to the hard phases. As a result, intra-particles microcracks (small voids) are generated and grow until some adjacent voids join together, forming large microcracks. The growth of microcracks continues with further particle cracking, causing rapid linking of voids and final fracture [41-43].
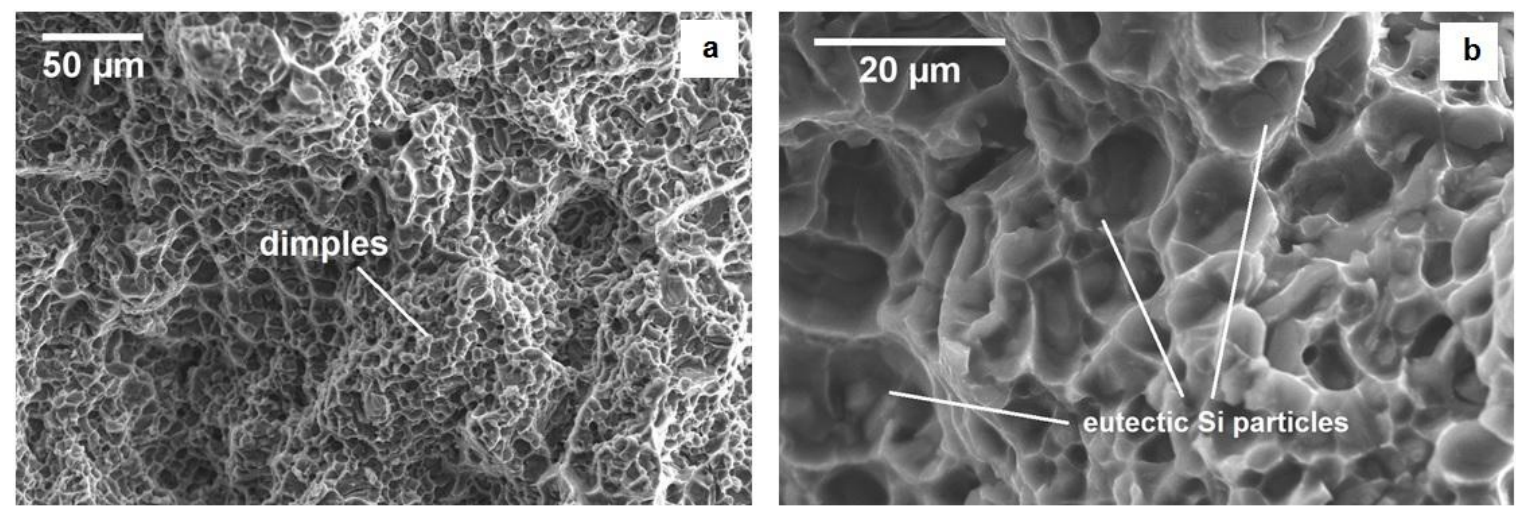

Figure 13. SEM micrographs of representative tensile fracture surfaces of A354-T6* alloy at (a) low and (b) high magnification.

\section{Conclusions}

The present work aimed to optimize the heat treatment parameters for A354 alloy, which is an Al-Si-Cu-Mg casting alloy employed for the production of engine cast components, in view of its high $\mathrm{Cu}$ content ( 1.5 wt.\%). This ensured an enhanced over-aging behavior in comparison to the more widely used ternary Al-Si-Mg alloys (e.g., A356, A357). As optimization criteria, heat treatment parameters were determined to ensure the maximum mechanical strength (in terms of HB, UTS, YS, maintaining good levels of ductility) while keeping at a minimum both the temperature and the time of treatment for industrial feasibility. The main conclusions are summarized below. 
- In order to avoid incipient melting during the solution treatment, a first solution stage consisting in $6 \mathrm{~h}$ at $495^{\circ} \mathrm{C}$ was required to dissolve the low melting compounds. A second solution stage at higher temperature $\left(515^{\circ} \mathrm{C}-2 \mathrm{~h}\right)$ was defined both to maximize hardness enhancement by bringing into the solution $\mathrm{Cu}$ and $\mathrm{Mg}$ in the $\alpha$-Al and making them available for artificial aging while maintaining treatment time and temperature as limited as possible. The quenching condition was kept fixed (water at $60^{\circ} \mathrm{C}$ ).

- The peak hardness for the A354 alloy (136 HB) was obtained after artificial aging for $6 \mathrm{~h}$ at $180{ }^{\circ} \mathrm{C}$ after the double stage solution treatment and quenching.

- Over aging curves highlighted the superior thermal stability of the quaternary A354 alloy in comparison to the ternary A356 alloy on account of the beneficial effect of Cu addition. Such behavior is related to the presence of $\mathrm{Cu}$-based $\mathrm{Q}$ quaternary precipitates induced by heat treatment in Al-Si-Cu-Mg alloys, which are reported in the literature to possess higher coarsening resistance in comparison to $\beta-\mathrm{Mg}_{2} \mathrm{Si}$ and $\theta-\mathrm{Al}_{2} \mathrm{Cu}$ phases found in ternary alloys.

- Compared to an industrial practice heat treatment, the proposed double stage heat treatment conferred to A354 alloy enhanced hardness and tensile strength at room temperature (HB, YS, UTS) while maintaining a good level of ductility. In addition, benefits in terms of high temperature $\left(210{ }^{\circ} \mathrm{C}\right)$ exposure resistance were registered.

Funding: This research received no external funding.

Acknowledgments: All the research activities were carried out in the framework of the DIMSAI PhD course at DIN (Department of Industrial Engineering) of Bologna University. The author gratefully acknowledges "Fondazione Aldo e Cele Daccò," for the Daccò Reward received at the 37th AIM National Congress for this research activity. Lorella Ceschini and Alessandro Morri (University of Bologna) are kindly acknowledged for their scientific support. The author thanks Simone Messieri (Ducati Motor Holding) for the fruitful collaboration on casting aluminum alloys.

\section{References}

1. Mondolfo, L. Aluminum Alloys: Structure \& Properties; Butterworths \& Co.: London, UK, 1976.

2. Mohamed, A.M.A.; Samuel, F.H.; Kahtani, S.A.l. Microstructure, tensile properties and fracture behavior of high temperature Al-Si-Mg-Cu cast alloys. Mater. Sci. Eng. A 2013, 577, 64-72. [CrossRef]

3. Lasa, L.; Rodrigues-Ibabe, J. Evolution of the main intermetallic phases in Al-Si-Cu-Mg casting alloys during solution treatment. J. Mater. Sci. 2004, 39, 1343-1355. [CrossRef]

4. Han, Y.; Samuel, A.M.; Doty, H.W.; Valtierra, S.; Samuel, F.H. Optimizing the tensile properties of Al-Si-Cu-Mg 319-type alloys: Role of solution heat treatment. Mater. Des. 2014, 58, 426-438. [CrossRef]

5. Kasprzak, W.; Amirkhiz, B.S.; Niewczas, M. Structure and properties of cast Al-Si based alloy with Zr-V-Ti additions and its evaluation of high temperature performance. J. Alloys Compd. 2014, 595, 67-79. [CrossRef]

6. Farkoosh, A.R.; Javidani, M.; Hoseini, M.; Larouche, D.; Pekguleryuz, M. Phase formation in as-solidified and heat-treated $\mathrm{Al}-\mathrm{Si}-\mathrm{Cu}-\mathrm{Mg}-\mathrm{Ni}$ alloys: Thermodynamic assessment and experimental investigation for alloy design. J. Alloys Compd. 2013, 551, 596-606. [CrossRef]

7. Farkoosh, A.R.; Pekguleryuz, M. Enhanced mechanical properties of an Al-Si-Cu-Mg alloy at $300{ }^{\circ} \mathrm{C}$ : Effects of Mg and the Q-precipitate phase. Mater. Sci. Eng. A 2015, 621, 277-286. [CrossRef]

8. Ceschini, L.; Morri, A.; Morri, A.; Toschi, S.; Johansson, S.; Seifeddine, S. Effect of microstructure and overaging on the tensile behavior at room and elevated temperature of C355-T6 cast aluminum alloy. Mater. Des. 2015, 83, 626-634. [CrossRef]

9. Ceschini, L.; Morri, A.; Toschi, S.; Johansson, S.; Seifeddine, S. Microstructural and mechanical properties characterization of heat treated and overaged cast A354 alloy with various SDAS at room and elevated temperature. Mater. Sci. Eng. A 2015, 648, 340-349. [CrossRef]

10. Hwang, J.Y.; Banerjee, R.; Doty, H.W.; Kaufman, M.J. The effect of Mg on the structure and properties of Type 319 aluminum casting alloys. Acta Mater. 2009, 57, 1308-1317. [CrossRef]

11. Sokolowski, J.H.; Djurdjevic, M.B.; Kierkus, C.A.; Northwood, D.O. Improvement of 319 aluminum alloy casting durability by high temperature solution treatment. J. Mater. Process. Technol. 2001, 109, 174-180. [CrossRef] 
12. Samuel, F. Incipient melting of $\mathrm{Al}_{5} \mathrm{Mg}_{8} \mathrm{Si}_{6} \mathrm{Cu}_{2}$ and $\mathrm{Al}_{2} \mathrm{Cu}$ intermetallics in unmodified and strontium-modified Al-Si-Cu-Mg (319) alloys during solution heat treatment. J. Mater. Sci. 1998, 33, 2283-2297. [CrossRef]

13. ASTM E 10-08 Standard Test Method for Brinell Hardness of Metallic Materials; ASM International: West Conshohocken, PA, USA, 2007.

14. ISO 6892-1:2009, Metallic Materials—Tensile Testing_Part 1: Method of Test at Room Temperature; ISO: Geneva, Switzerland, 2009.

15. Sjölander, E.; Seifeddine, S. Optimization of Solution Treatment of Cast Al-7Si-0.3Mg and Al-8Si-3Cu- $0.5 \mathrm{Mg}$ Alloys. Metall. Mater. Trans. A 2014, 45, 1916-1927. [CrossRef]

16. Li, Z.; Samuel, A.M.; Samuel, F.H.; Ravindran, C.; Valtierra, S. Effect of alloying elements on the segregation and dissolution of $\mathrm{CuAl}_{2}$ phase in Al-Si-Cu 319 alloys. J. Mater. Sci. 2003, 38, 1203-1218. [CrossRef]

17. Han, Y.M.; Samuel, A.M.; Samuel, F.H.; Doty, H.W. Dissolution of $\mathrm{Al}_{2} \mathrm{Cu}$ phase in non-modified and $\mathrm{Sr}$ modified 319 type alloys. Int. J. Cast Met. Res. 2008, 21, 387-393. [CrossRef]

18. Lu, T.; Wu, J.; Pan, Y.; Tao, S.; Chen, Y. Optimizing the tensile properties of Al-11Si-0.3Mg alloys: Role of Cu addition. J. Alloys Compd. 2015, 631, 276-282. [CrossRef]

19. Javidani, M.; Larouche, D.; Chen, X.G. Dissolution of $\mathrm{Cu} / \mathrm{Mg}$ Bearing Intermetallics in Al-Si Foundry Alloys. Metall. Mater. Trans. A 2016, 47, 4818-4830. [CrossRef]

20. Bäckerud, L.; Chai, G.; Tamminen, J. Solidification Characteristics of Aluminum Alloys. Volume 2, Foundry alloys; Department of Structural Chemistry, University of Stockholm, AFS/Skanaluminium: Oslo, Sweden, 1990.

21. Toschi, S. Cast Aluminum Alloys and Al-Based Nanocomposites with Enhanced Mechanical Properties at Room and High Temperature: Production and Characterization. Ph.D. Thesis, University of Bologna, Bologna, Italy, April 2016.

22. Wang, G.; Bian, X.; Wang, W.; Zhang, J. Influence of $\mathrm{Cu}$ and minor elements on solution treatment of Al-Si-Cu-Mg cast alloys. Mater. Lett. 2003, 57, 4083-4087. [CrossRef]

23. Samuel, A.; Doty, H.; Valtierra, S.; Samuel, F. Defects related to incipient melting in Al-Si-Cu-Mg alloys. Mater. Des. 2013, 52, 947-956. [CrossRef]

24. Sandoval, J.H.; Mohamed, A.M.; Valtierra, S.; Samuel, F.H. Mechanical Performance of a cast A354 Aluminium Alloy. Mater. Sci. Forum 2014, 794-796, 489-494. [CrossRef]

25. Mohamed, A.; Samuel, F.H.; Kahtani, S.A.l. Microstructure, tensile properties and fracture behavior of high temperature Al-Si-Mg-Cu cast alloys. Mater. Sci. Eng. A 2013, 577, 64-72. [CrossRef]

26. Samuel, F.H.; Samuel, A.M.; Liu, H. Effect of magnesium content on the ageing behavior of water-chilled Al-Si-Cu-Mg-Fe-Mn (380) alloy castings. J. Mater. Sci. 1995, 30, 2531-2540. [CrossRef]

27. Lasa, L.; Rodriguez-Ibabe, J. Characterization of the dissolution of the $\mathrm{Al}_{2} \mathrm{Cu}$ phase in two $\mathrm{Al}-\mathrm{Si}-\mathrm{Cu}-\mathrm{Mg}$ casting alloys using calorimetry. Mater. Charact. 2002, 48, 371-378. [CrossRef]

28. Moustafa, M.A.; Samuel, F.H.; Doty, H.W. Effect of solution heat treatment and additives on the hardness, tensile properties and fracture behaviour of Al-Si (A413.1) automotive alloys. J. Mater. Sci. 2003, 38, 4523-4534. [CrossRef]

29. Alfonso, I.; Maldonado, C.; Gonzalez, G.; Bedolla, A. Effect of Mg content and solution treatment on the microstructure of Al-Si-Cu-Mg alloys. J. Mater. Sci. 2006, 41, 1945-1952. [CrossRef]

30. Sjölander, E.; Seifeddine, S. Artificial ageing of Al-Si-Cu-Mg casting alloys. Mater. Sci. Eng. A 2011, 528, 7402-7409. [CrossRef]

31. Taylor, J.A. The Effect of Iron in Al-Si Casting Alloys. In Proceedings of the 35th Australian Foundry Institute National Conference, Adelaide, South Australia, 31 October-3 November 2004.

32. Taylor, J.; St. John, D.; Zheng, L.; Edwards, G.; Barresi, J.; Couper, M. Solution treatment effects in Al-Si-Mg casting alloys: Part 1-Intermetallic phases. Alum. Trans. Int. J. 2001, 4-5, 95-100.

33. Mbuya, T.; Odera, B.; Ng'ang'a, S.P. Influence of iron on castability and properties of aluminium silicon alloys: Literature review. Int. J. Cast Met. Res. 2003, 16, 451-465. [CrossRef]

34. Ibrahim, M.F.; Samuel, E.; Samuel, A.M.; Al-Ahmari, A.M.A.; Samuel, F.H. Metallurgical parameters controlling the microstructure and hardness of Al-Si-Cu-Mg base alloys. Mater. Des. 2011, 32, 2130-2142. [CrossRef]

35. Ammar, H.R.; Samuel, A.M.; Samuel, F.H.; Simielli, E.; Sigworth, G.K.; Lin, J.C. Influence of Aging Parameters on the Tensile Properties and Quality Index of Al-9 Pct Si-1.8 Pct Cu-0.5 Pct Mg 354-Type Casting Alloys. Metall. Mater. Trans. A 2011, 43, 61-73. [CrossRef] 
36. Li, R.X.; Li, R.D.; Zhao, Y.H.; He, L.Z.; Li, C.X.; Guan, H.R.; Hu, Z.Q. Age-hardening behavior of cast Al-Si base alloy. Mater. Lett. 2004, 58, 2096-2101. [CrossRef]

37. Cerri, E.; Evangelista, E.; Spigarelli, S.; Cavaliere, P.; Dericcardis, F. Effects of thermal treatments on microstructure and mechanical properties in a thixocast 319 aluminum alloy. Mater. Sci. Eng. A 2000, 284, 254-260. [CrossRef]

38. Lifshitz, I.M.; Slyozov, V.V. The kinetics of precipitation from supersaturated solid solutions. J. Phys. Chem. Solids 1961, 19, 35-50. [CrossRef]

39. Knipling, K.E.; Dunand, D.C.; Seidman, D.N. Criteria for developing castable, creep-resistant aluminum-based alloys-A review. Zeitschrift Für Metall. 2006, 97, 246-265. [CrossRef]

40. Farkoosh, A.R.; Chen, X.G.; Pekguleryuz, M. Dispersoid strengthening of a high temperature Al-Si-Cu-Mg alloy via Mo addition. Mater. Sci. Eng. A 2015, 620, 181-189. [CrossRef]

41. Wang, Q.G. Microstructural Effects on the Tensile and Fracture Behavior of Aluminum Casting Alloys A356/357. Metall. Mater. Trans. A 2003, 34, 2887-2899. [CrossRef]

42. Caceres, C.H.; Davidson, C.; Griffiths, J. The deformation and fracture behaviour of an Al-Si-Mg casting alloy. Mater. Sci. Eng. A 1995, 197, 171-179. [CrossRef]

43. Casari, D.; Merlin, M.; Garagnani, G.L. A comparative study on the effects of three commercial Ti-B-based grain refiners on the impact properties of A356 cast aluminium alloy. J. Mater. Sci. 2013, 48, 4365-4377. [CrossRef]

(C) 2018 by the author. Licensee MDPI, Basel, Switzerland. This article is an open access article distributed under the terms and conditions of the Creative Commons Attribution (CC BY) license (http:/ / creativecommons.org/licenses/by/4.0/). 